Araştırma Makalesi
Adıyaman Üniversitesi
Mühendislik Bilimleri Dergisi

\title{
MODELLING OF CRUST STRUCTURE OF CENTRAL ANATOLIA REGION
}

\author{
Ali ELMAS ${ }^{*}$ \\ ${ }^{1}$ Karadeniz Technical University, Faculty of Engineering, Department of Geophysics, 61080, Trabzon, Turkey \\ Geliş Tarihi/Received Date: 14.06.2021 Kabul Tarihi/Accepted Date: 07.08.2021 DOI: 10.54365/adyumbd.952257
}

\begin{abstract}
In this study, the crustal structure of Central Anatolia was modeled and the crustal and tectonic structure of the region was investigated. For this purpose, the filtered satellite gravity data were evaluated with the ParkerOldenburg modelling algorithm and the first vertical derivative data were evaluated with the total horizontal derivative technique. While investigating the structural discontinuities of the region at the basement levels, the maximum amplitudes of the horizontal derivative map were used. With the total horizontal derivative map, new discontinuities were found in the basement levels in the study area. The descending and rising parts of the crustal interface topographies were determined using the Parker-Oldenburg modelling algorithm. In order to carry out these operations, first of all, the gravity data was filtered according to the shear wave numbers. Besides the new lineaments found, the depths of the calculated interface topographies are determined as $1.4-3.6 \mathrm{~km} \mathrm{for} \mathrm{soft} \mathrm{-}$ hard sediment, 3.8 - 7.2 km for basement, 15.5 - 22.5 km for Conrad, 30.5 - $39.5 \mathrm{~km}$ for Moho and 81.4 - 88.5 $\mathrm{km}$ for LAB, respectively.
\end{abstract}

Keywords: Central Anatolia; Horizontal Derivative; Vertical Derivative; Discontinuity; Modelling

\section{İÇ ANADOLU BÖLGESİ KABUK YAPISININ MODELLENMESI}

\section{ÖZET}

Bu çalışmada, İç Anadolu'nun kabuk yapısı modellenmiştir ve bölgenin kabuk ve tektonik yapısı araştırılmıştır. $\mathrm{Bu}$ nedenle filtrelenmiş uydu gravite verileri modelleme tekniği ile değerlendirilmiş ve düşey birinci türev verileri toplam yatay türev tekniği ile değerlendirilmiştir. Bölgenin yapısal süreksizlikleri temel kaya seviyelerinde araştırılırken, yatay türev haritasının maksimum genliklerinden yararlanılmıştır. Toplam yatay türev haritası ile çalışma alanındaki temel kaya seviyelerinde yeni süreksizlikler bulunmuştur. Kabuksal arayüz topografyalarındaki alçalma ve yükselme kısımları Parker-Oldenburg inversiyon algoritması kullanılarak belirlendi. Bu işlemlerin yapılabilmesi için öncelikle gravite verileri kesme dalgası sayılarına göre filtrelenmiştir. Bulunan yeni çizgiselliklerin yanı sıra, hesaplanan ara yüzey topografyalarının derinlikleri sırasıyla yumuşak - sert sediment için 1,4 - 3,6 km, temel kaya için 3,8 - 7,2 km, Conrad için 15,5 - 22,5 km, Moho için 30,5 - 39,5 km ve LAB için 81,4 - 88,5 km olarak belirlenmiştir.

Anahtar Kelimeler: İç Anadolu; Yatay Türev; Düşey Türev; Süreksizlik; Modelleme

\section{Introduction}

The tectonic model and the faulting of Central Anatolia (Figure 1) were preliminarily handled by [27]. [12], [14] proposed the other tectonic model between Şereflikoçhisar-Aksaray and Ecemiş Faults to give the diapiric salt improvements that are in the Salt Lake Basin. [30] found the sediment thickness of around salt lake located in the middle of the study area as $1.2-2 \mathrm{~km}$ with $2 \mathrm{D}$ gravity inverse analysis. [6] examined the tectonic structure of Central Anatolia using aeromagnetic, seismic, seismological and gravity data. [3] performed the curie point depth investigation using regional aeromagnetic anomalies

\footnotetext{
*1 e-mail: elmas@,ktu.edu.tr ORCID ID: https://orcid.org/0000-0003-3343-2742 (Sorumlu Yazar),
} 
of the Central Anatolia. They found that the curie point depths of Central Anatolia varies from $7.9 \mathrm{~km}$ to $22.6 \mathrm{~km}$. [4] evaluated the preliminary evaluation of the basins in the study area using the gravity and magnetic data. [5] showed the basement topography depth of the study area by 3D modeling. Found depth values of basement topography were $8 \mathrm{~km}$ around Haymana, $10 \mathrm{~km}$ around Bala, $5.5 \mathrm{~km}$ to the west of Salt Lake and 8-13 km around the salt lake basin. [13] studied the structural evolution of the Salt Lake Basin. [20] studied the tectonic evolution of the Central Anatolian basins. [9] investigated the regional wrench tectonics of inner East Anatolia using potential field data. [32] found that the depth of moho varies between $37-47 \mathrm{~km}$ for Central Anatolia using receiver function analysis of seismic data.

Regional or residual gravity data are used in discontinuity studies using horizontal gradient magnitude (HGM) data [1, 10]. Rather than gravity data, [17] has shown for the first time that vertical derivative data is more useful in determining the lineaments. In order to determine the gravity produced by the basement levels of the Central Anatolia, a band-pass filter was used according to certain cut-off wave numbers. The cut-off wave numbers used in this process were determined from the amplitude spectrum for basement. Then, Fast Fourier transform (FFT) technique [21] was used to calculate the vertical derivative (VD) values of the filtered data determined for the basement levels. POTENSOFT program developed by [2] was used to perform the data filtering and lineament analysis. Parker (1973) calculated the gravity anomaly caused by an uneven, uniform layer of material by means of a series of Fourier transforms [26]. Oldenburg (1974) rearranged his equation to compute the depth to the undulating interface from the gravity anomaly profile by means of an iterative process [22]. [19] have written this algorithm with Matlab programming language. [18] have shown that this program gives erroneous results. This algorithm has been used with a certain error acceptance in inverse solution operations in order to reveal the descending and rising areas of crustal interfaces with depth information of Central Anatolian region.

Since the focal depths of the earthquakes near the study area are mostly at the first $10 \mathrm{~km}$ depth [23], in this study, lineaments are investigated at basement levels. For this reason, the VD values of the filtered data for the basement obtained from the Bouguer gravity data of Central Anatolia is used. HGM technique is applied to the VD values and the existence of new discontinuities as well as known discontinuities are investigated. Subsequently, the hard-soft sediment, basement, Conrad, Moho and lithosphere-asthenosphere boundary (LAB) interface topographies of the region are tried to calculate by inversion using the filtered gravity data that are filtered according to certain cut-off wave numbers from the Bouguer gravity data of the study area. VD, HGM and inversion operations are performed and the current tectonics and crustal structure of Central Anatolia are tried to be modeled.

\section{General Geology of Central Anatolia}

Central Anatolia is generally covered with young sediments [5]. The old sediments are found in small areas around the Salt Lake Basin. Sedimentary units in the area are surrounded by the Sakarya, Kurşehir Metamorphics and Kütahya - Bolkardağ 1 Metamorphics units of the Menderes-Toros Platforms [29]. The ophiolite remains belonging to the northern branch of the Tethys Ocean are located to the north of Salt Lake. In addition, terrestrial volcanic rocks, which are formed by tectonic activities at different geological times, are found in limited areas (Figure 1). These volcanic rocks are of the same age as the tectonic periods in Central Anatolia [8]. Sediments in the Salt Lake Basin were studied by [5]. The map showing the active fault zones in the study area is shown in Figure 2. SAF, KirikkaleErbaa (KEF) and Ecemis (EF) Faults are known and compatible with the tectonics in the study area (Figure 1). The study area includes the Central Anatolian Thrust Belt (CATB) and the Almus Fault (AF) to the north of this belt. SAF and KEF are crossed at Hinge Point (HP) at the south of Ankara (Figures 1 and 2). In addition, the North Anatolian Fault Zone (NAFZ), which has a high destructive effect, also passes through the north of the region (Figure 2). 


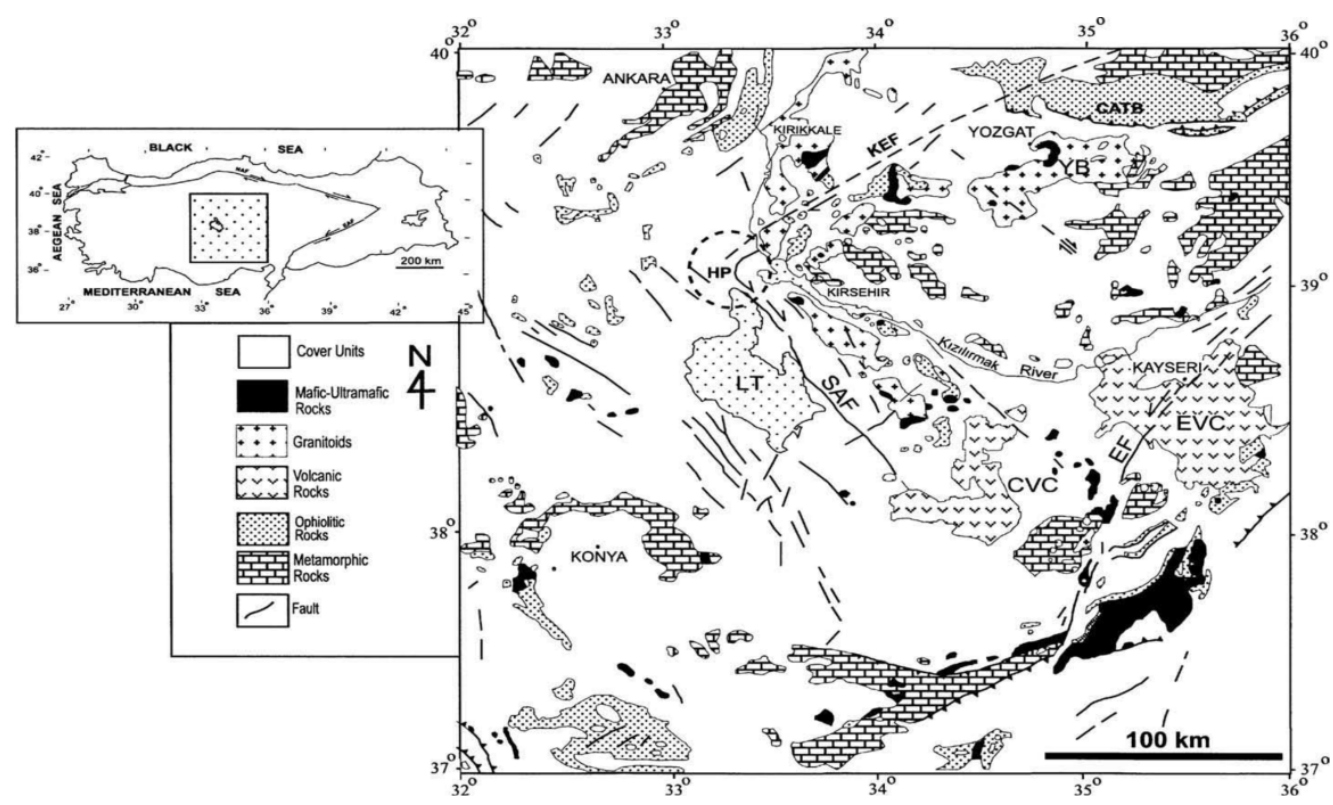

Figure 1. Generalized geological map of the Central Anatolia (after [3]).

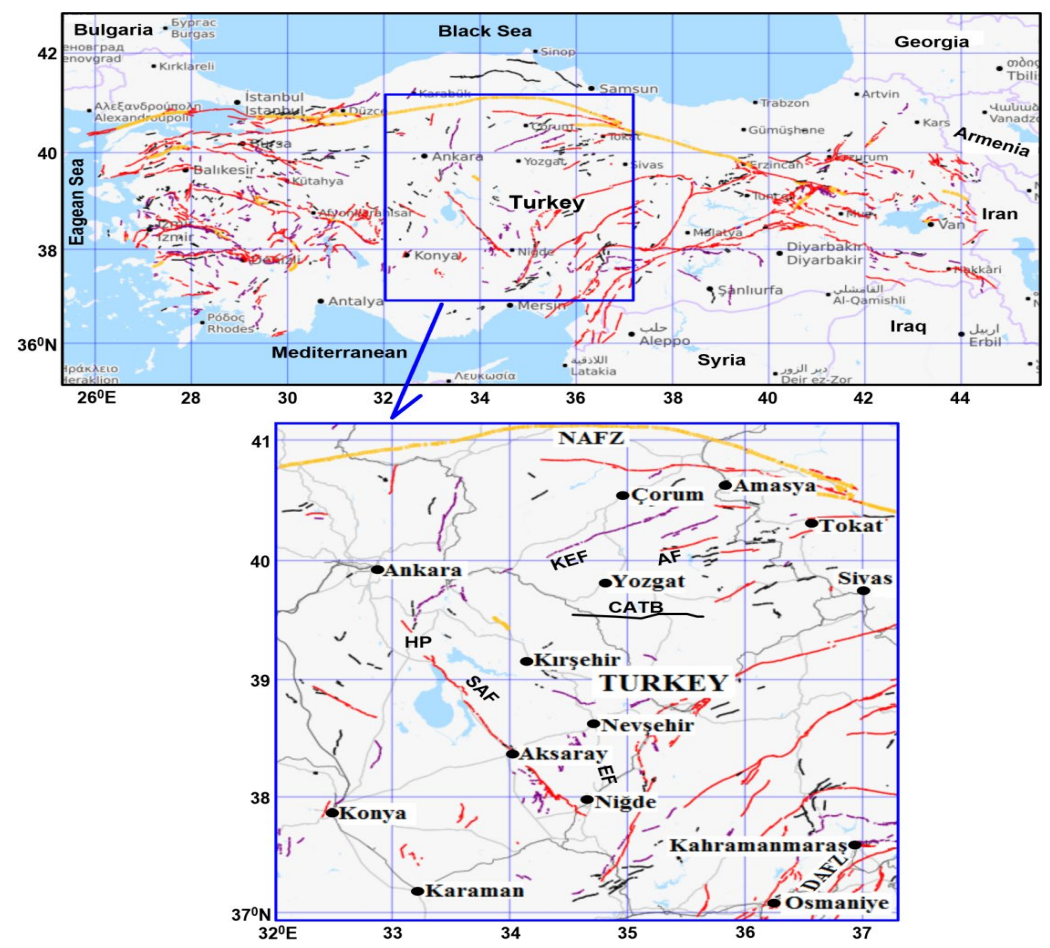

Figure 2. Active fault zone map of Central Anatolia (after [16]).

\section{Central Anatolia EGM08 Bouguer Anomalies and Topography Data}

[27] published the Earth Gravitational Model that has high resolution in 2008. The availability of the Earth Gravity Model (EGM08) model has been proven by a number of scientists [23]. These scientists proved that EGM08 is the best tested model. In this study, gravity data of the study area was compiled from EGM08 model (Figure 3a) [27]. Minimum gravity values are seen in the area between 
Sivas, Yozgat, Aksaray and Kahramanmaraş provinces, while maximum gravity values are seen in the northeast of the region and in the west of Osmaniye province.
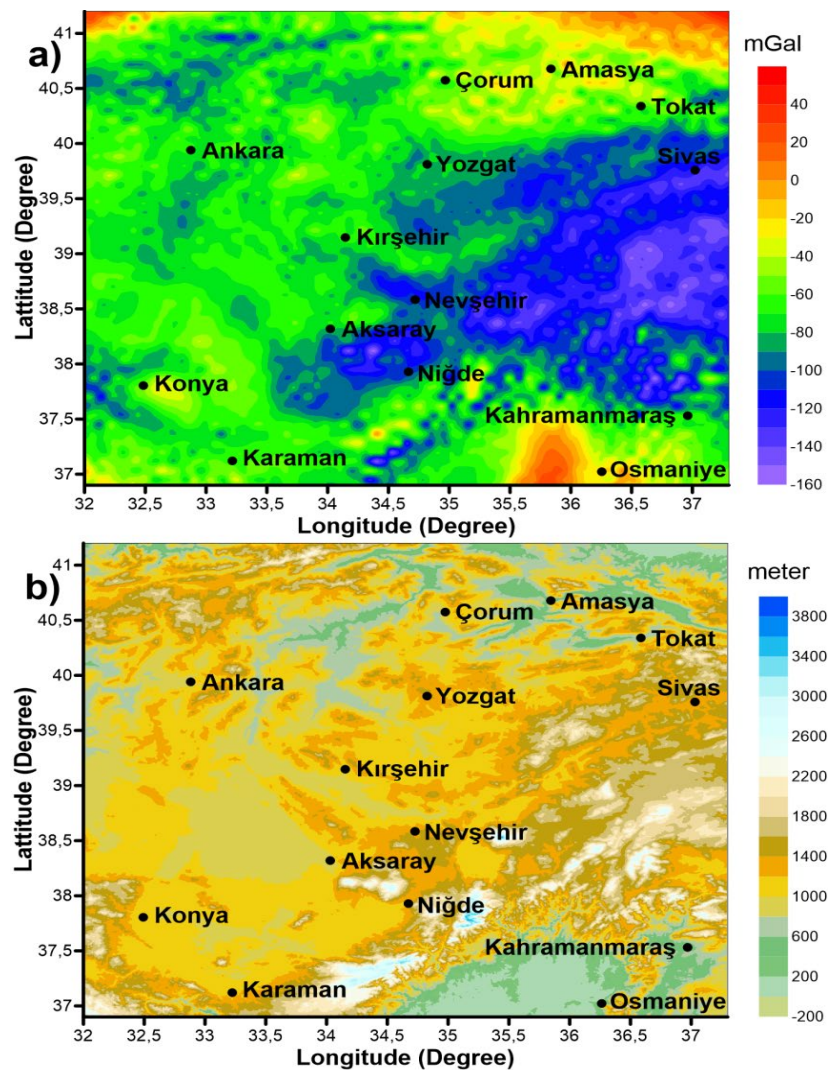

Figure 3. a) EGM08 Bouguer anomaly, and b) topography maps of Central Anatolia.

The low gravity values on the relatively high mountain masses that have low density are about $150 \mathrm{mGal}$ levels (Figure 3a). This is generally related to the reduction of the gravity values produced by the increase in the depth of the astenosphere material which has a high density as a result of the increase in the thickness of the crust in these parts. The topography data of study area shown in Figure $3 \mathrm{~b}$ was obtained from the Global Digital Elevation Model (GTOPO30) [31]. When both figures are considered together, it is seen that the gravity and topography data are clearly inversely proportional to each other. That is to say, if a general evaluation is made, gravity values have decreased in mountainous areas where topography values have increased in Central Anatolia.

The mean depths of the crust interfaces of the area in this study were determined using the radial mean amplitude spectrum technique developed by [7]. The process in this technique depends on the 2D Fourier transform of gravity data. The depths of interfaces to be calculated are obtained from the slopes of the linear relationship between the wave numbers and the radial mean amplitude spectrum of the gravity data. As a result of the calculations made with the gravity data used in this study, five different interface depths were found (Figure 4). The mean depths of the soft-hard sediment, Basement, Conrad, Moho and LAB interface boundaries from the sloping parts of the radial mean amplitude spectrum were 2.7, 5.7, 19.0, 34.6 and $85.6 \mathrm{~km}$, respectively (Figure 4).

The Parker-Oldenburg algorithm was used to model the interface topographies using the average depth values found using the amplitude spectrum technique. This algorithm is depended on the connection between the Fourier transform of the interface topography and the Fourier transform of the gravity values. This connection is recursively formed from the density difference and determined depth 
of an interface of geological structure $[22,26]$. Fourier transform utilized to compute gravity values of an irregular homogeneous unit is as follows [26]:

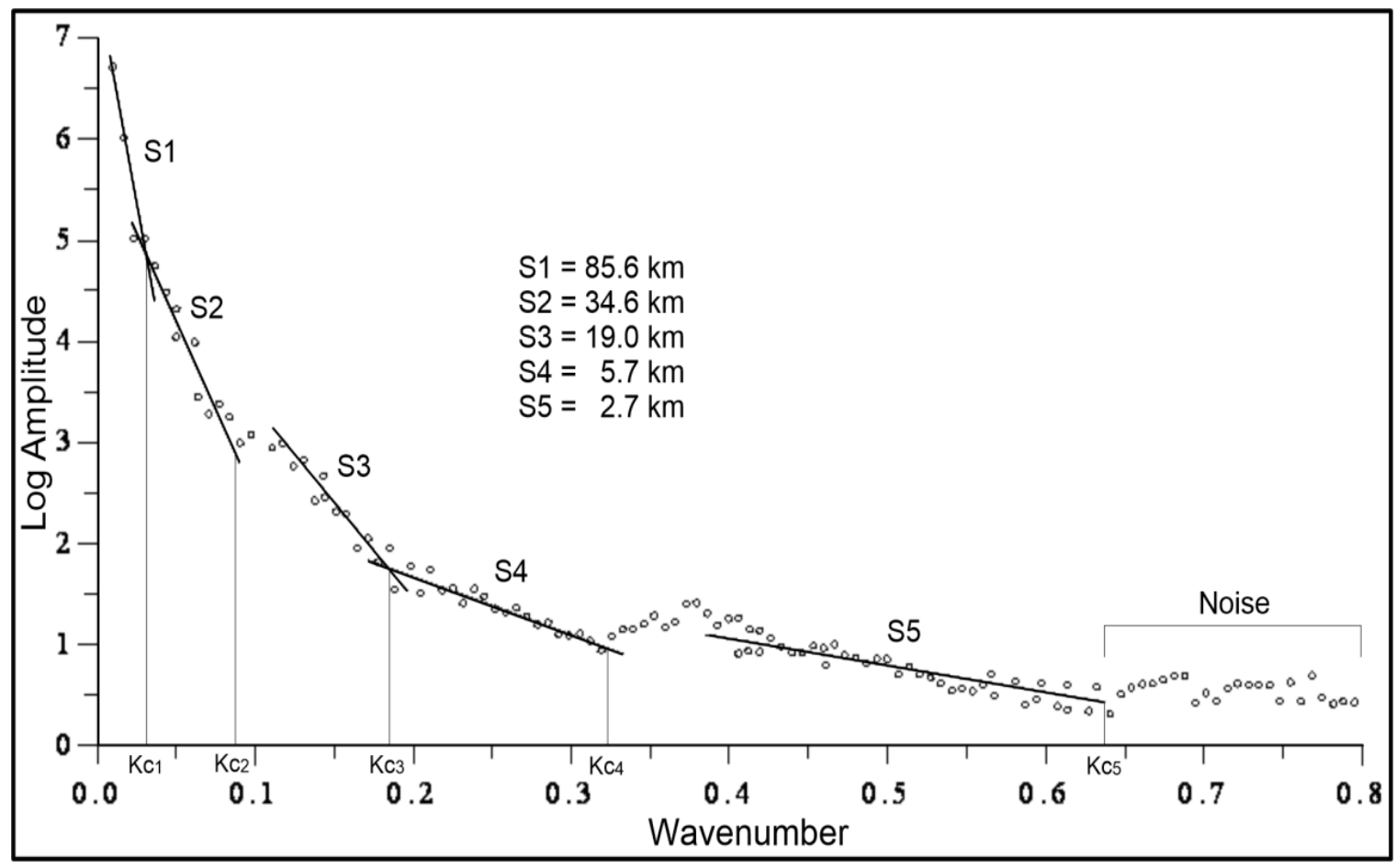

Figure 4. Radial mean amplitude spectrum of Central Anatolia EGM08 Bouguer anomalies and determination of mean depths and critical wave numbers of deep interface boundaries.

$$
g[x, y]=F^{-1}\left\{-2 \pi G \Delta \rho e^{-z_{0} \sqrt{\left(k_{x}^{2}+k_{y}^{2}\right)}} \sum_{n=1}^{\infty} \frac{|k|^{n-1}}{n !} F\left[h^{n}(x, y)\right]\right\}
$$

where $G$ is the universal gravity constant, $\Delta \rho$ is the density difference, $h(x, y)$ boundary depths, $k_{x}$ and $k_{y}$ are the wave numbers in the $x$ and $y$ direction, $n$ degree of undulation and $F^{-1}$ inverse Fourier transform. For the inverse solution of boundary undulation based on gravity anomalies, [22] gives the equation as:

$$
f\left[h_{1}(x, y)\right]=-\frac{f[\Delta g(x, y)] e^{|k| h_{0}}}{2 \pi G \rho}-\sum_{n=2}^{\infty} \frac{|k|^{n-1}}{n !} f\left[h_{1}^{n}(x, y)\right],
$$

where $f[\Delta g(x, y)], h_{0}, h_{1}(x, y), k, G$, and $\rho$ are the Fourier transform of the gravity values, average depth, depth under each measurement point, wavenumber, gravitational constant, and the difference of the densities above and below the boundary, respectively. Formula 2 is utilized to compute densitiy interface iteratively utilizing $h_{0}$ and $\Delta g(x, y)$. The first prediction of the depth of interface are ensured by inverse Fourier transform. Also, this interface value can be utilized to find the right of Formula 2. For this reason, this cause to be finalizing the second depth reaches findings. The iterations keep up till the convergence measure is arrived. In short, it is taken into account that the root mean square (RMS) errors between the estimated depths $h(x, y)$ at the end of two consecutive iterations are less than a near-zero convergence criterion $(0.01 \mathrm{~km})$. 


\section{Technique of Determining Discontinuities}

[11] proposed the HGM technique to reveal the lateral boundaries of the masses. The HGM technique, which is especially useful for displaying the relationship between potential field data and shallow or deep faults, is used to determine the lateral discontinuity limits of geological structures. The amplitude of HGM is expressed as given in Formula 3 [25] according to the first vertical derivative (FVD) values:

$$
H G M=\sqrt{\left(\frac{\partial^{2} g}{\partial x \partial z}\right)^{2}+\left(\frac{\partial^{2} g}{\partial y \partial z}\right)^{2}}
$$

The terms $\frac{\partial^{2} \mathrm{~g}}{\partial \mathrm{x} \partial \mathrm{z}}$ and $\frac{\partial^{2} \mathrm{~g}}{\partial \mathrm{y} \partial \mathrm{z}}$ here refer to derivatives of the FVD values of the regional gravity data in the $\mathrm{x}$ - and $\mathrm{y}$-directions.
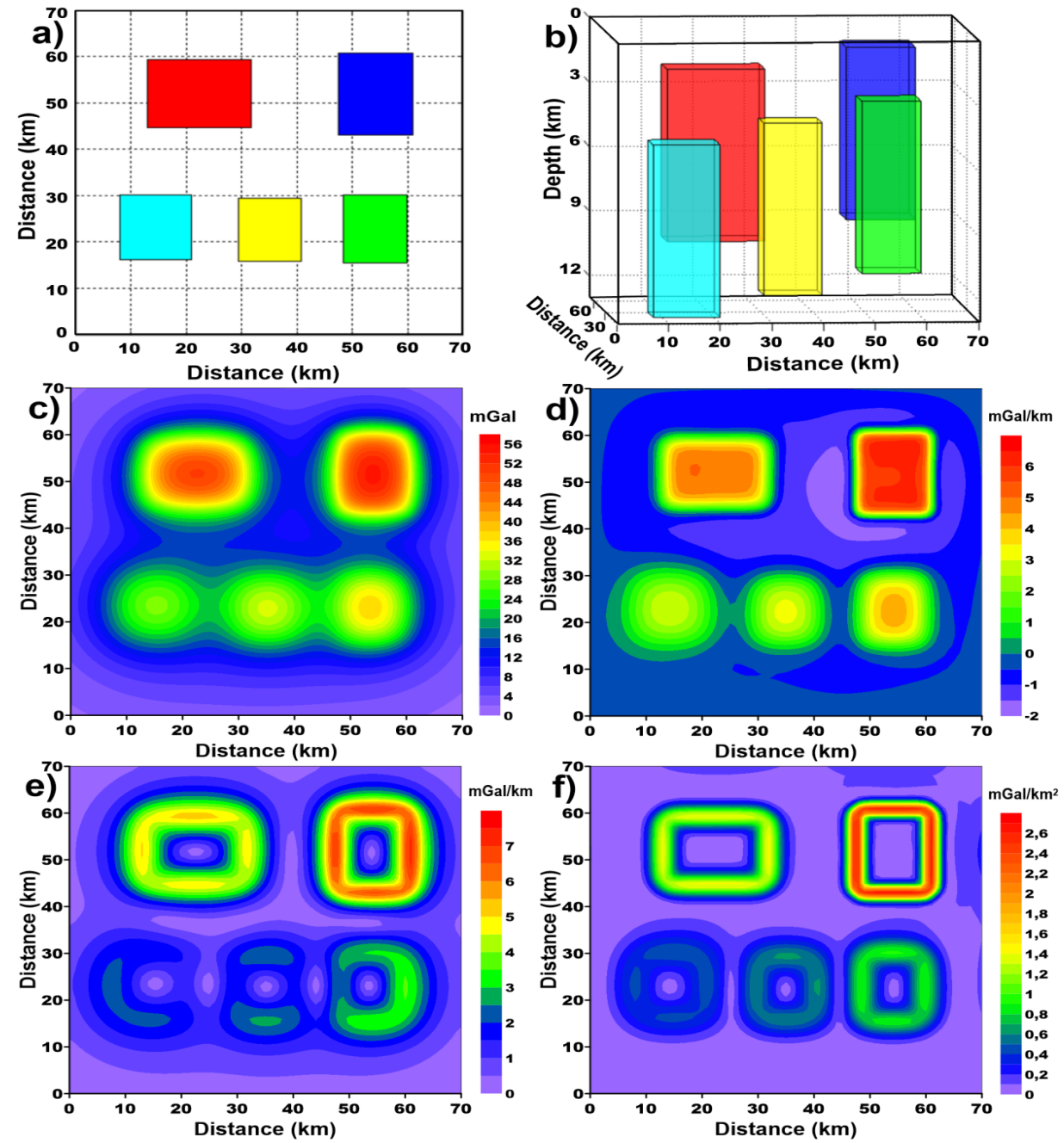

Figure 5. a) Finite vertical prismatic models, b) 3D view of the models, c) gravity map of the models,

d) VD map of the gravity, e) HGM map of the gravity, f) HGM map of the VD values. 
Figures $5 \mathrm{a}$ and $5 \mathrm{~b}$ show a theoretical model consisting of five rectangular bodies with unlike dimensions and depths having a density difference of $0.3 \mathrm{~g} / \mathrm{cm}^{3}$. POTENSOFT software which was designed by [2] was used to make the linear structure determination study with the theoretical model. Depths of bodies forming the model were determined as 1, 2, 3, 4 and $5 \mathrm{~km}$, respectively (Figure 5b). Gravity map produced by the model is given in Figure 5c. VD map of generated gravity values is given in Figure 5d. When the determined gravity and VD maps are evaluated together, it is understood that derivative map is more helpful than gravity anomaly in order to determine lateral boundaries of objects at different depths. In other words, in the vertical derivative map, the boundaries of the masses resulting from the density difference become more apparent. Then, the gravity values and VD values were tested by HGM technique to reveal the data that were more successful in determining the mass boundaries (Figures 5e and 5f). According to the results obtained using HGM technique, as the depth of the object increases, the determination of the lateral boundaries of this object decreases (Figures 5e and 5f). In addition, the lineaments found with the derivative data (Figure 5f) appear to be more accurate than the lineaments found in the gravity data (Figure 5e). When the figures are examined, it can be seen that the boundaries detected with the HGM of the gravity data do not represent the real boundaries well, but the boundaries obtained with the HGM of the vertical derivative data delineate the actual boundaries of the structures well.

\section{Performed Works}

Band-pass filter is used to obtain filtered gravity data of interfaces of the region using the cut-off wavenumbers. The maximum values of HGM amplitudes computed from FVD values of filtered gravity data for basement represent tectonic discontinuities and lineaments in study area. In this study, lineament research was conducted at the basement levels. The reason for determining these depth levels is that the focal depths of the earthquakes in the vicinity of the study area occur at $10 \mathrm{~km}$ below the surface [23]. The crust structure of the study area is shown in Figure 6a. Also, Figure 6b shows the VD anomaly map obtained from filtered gravity data of basement. When the VD map is examined, the masses whose densities are higher than the surrounding rocks became more visible. As indicated in the theoretical model study, it can be said that the discontinuities determined in Figures $6 \mathrm{c}$ calculated using the derivative data correspond to tectonic units of region. Compared to Figures $6 \mathrm{a}$ and $6 \mathrm{c}$, the known faults could be re-determined by the HGM technique. In addition, the new fault type structures in some parts of the study area and the mass boundaries presenting the density difference are seen in the HGM amplitude map. Some of the obtained lineaments represent active faults, some of them are old faults and some of them represent the mass boundaries that present the density difference. When looking at the HGM map, both the newly discovered lineaments and the NAFZ that pass north of the study area, CATB, SAF, KEF and other important faults can be seen. As a result of the HGM account, known faults and new lineaments resulting from the density difference are seen in Figure 6c. When this figure is considered, new lineaments presenting the density difference, which are parallel to the existing faults in some parts of the study area and are close to these faults are determined. The lineaments found in this study for the basement levels and the tectonic structure that was given by [6] are widely compatible. In particular, several lineaments extending parallel to NAFZ have been identified (Figure 6c). In some sections, new lineaments offering density difference have been found, which cut the known faults.

The soft-hard sediment, basement, Conrad, Moho and LAB topographies of the study area are modeled (Figures $7 \mathrm{~b}, 7 \mathrm{~d}, 7 \mathrm{f}, 7 \mathrm{~h}$ and $7 \mathrm{j}$ ) by applying the Parker-Oldenburg algorithm to the filtered gravity data that are obtained by band-pass filtering according to certain cut-off wave numbers (Figures $7 \mathrm{a}, 7 \mathrm{c}, 7 \mathrm{e}, 7 \mathrm{~g}$ and $7 \mathrm{i}$ ). Here, the convergence criterion was $0.01 \mathrm{~km}$ and the number of iterations was 5 . In order to calculate these topographies, depth values of 2.7, 5.7, 19.0, 34.6 and $85.6 \mathrm{~km}$ from the amplitude spectrum are used as initial depth values for soft-hard sediment, basement, Conrad, Moho and LAB topographies, respectively. The density difference between the lower sediment $\left(\sim 2.55 \mathrm{~g} / \mathrm{cm}^{3}\right)$ and the upper sediment $\left(\sim 2.25 \mathrm{~g} / \mathrm{cm}^{3}\right)$ is determined as $0.3 \mathrm{~g} / \mathrm{cm}^{3}$ to calculate the soft-hard sediment interface topography. The density difference between the metamorphic unit $\left(\sim 2.7 \mathrm{~g} / \mathrm{cm}^{3}\right)$ and Neogene 
sediment $\left(\sim 2.4 \mathrm{~g} / \mathrm{cm}^{3}\right)$ to the depth of the basement is determined as $0.3 \mathrm{~g} / \mathrm{cm}^{3}$ to calculate the basement interface topography [15]. The density difference between the lower crust $\left(\sim 2.93 \mathrm{~g} / \mathrm{cm}^{3}\right)$ and the upper crust $\left(\sim 2.67 \mathrm{~g} / \mathrm{cm}^{3}\right)$ is determined as $0.26 \mathrm{~g} / \mathrm{cm}^{3}$ to calculate the Conrad interface topography. The density difference between the lithospheric mantle $\left(\sim 3.28 \mathrm{~g} / \mathrm{cm}^{3}\right)$ and the crust $\left(\sim 2.72 \mathrm{~g} / \mathrm{cm}^{3}\right)$ is determined as $0.56 \mathrm{~g} / \mathrm{cm}^{3}$ to calculate the Moho interface topography [24]. Finally, the density difference between the asthenospheric mantle $\left(\sim 3.32 \mathrm{~g} / \mathrm{cm}^{3}\right)$ and the lithospheric mantle $\left(\sim 3.28 \mathrm{~g} / \mathrm{cm}^{3}\right)$ is determined as $-0.04 \mathrm{~g} / \mathrm{cm}^{3}$ to calculate the LAB interface topography [24]. In the calculation for the LAS topography, the density difference is taken as negative due to gravity anomalies [24]. The cut-off wave numbers are determined from the amplitude spectrum as $0.32 \mathrm{~km}^{-1}$ and $0.64 \mathrm{~km}^{-1}$ for the soft-hard sediment, $0.18 \mathrm{~km}^{-1}$ and $0.32 \mathrm{~km}^{-1}$ for the basement, $0.09 \mathrm{~km}^{-1}$ and $0.18 \mathrm{~km}^{-1}$ for the Conrad, $0.03 \mathrm{~km}^{-1}$ and $0.09 \mathrm{~km}^{-1}$ for the Moho and $0.0 \mathrm{~km}^{-1}$ and $0.03 \mathrm{~km}^{-1}$ for the LAB respectively. The depths of the calculated interface topographies are determined as $1.4-3.6 \mathrm{~km}$ for soft - hard sediment, $3.8-7.2 \mathrm{~km}$ for basement, 15.5 - $22.5 \mathrm{~km}$ for Conrad, 30.5 - $39.5 \mathrm{~km}$ for Moho and $81.4-88.5 \mathrm{~km}$ for LAB, respectively (Figures $7 \mathrm{~b}, 7 \mathrm{~d}, 7 \mathrm{f}, 7 \mathrm{~h}$ and $7 \mathrm{j}$ ).
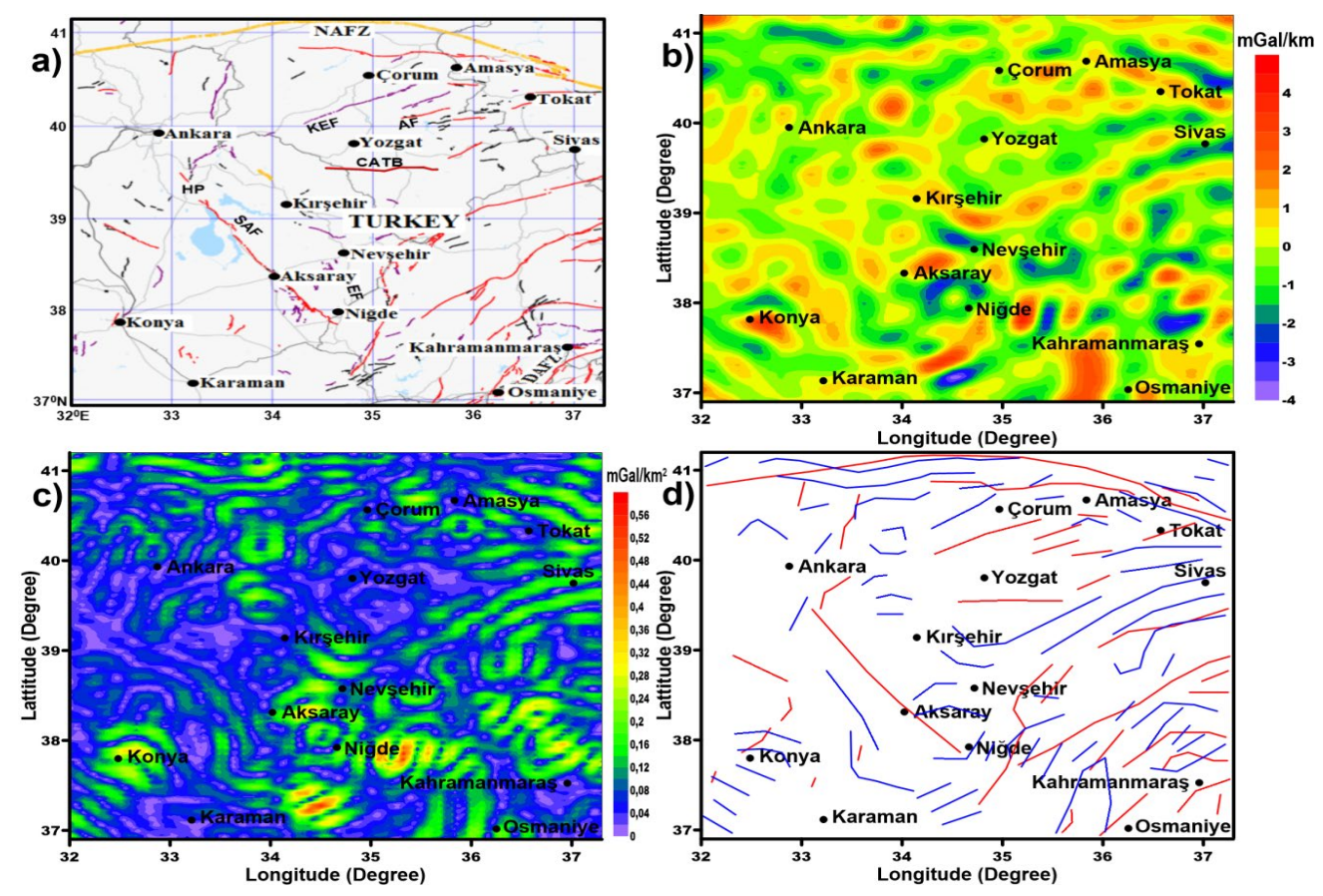

Figure 6. a) Study area, b) The VD map of the filtered gravity data for basement, c) HGM map of the VD data, d) Known faults of study area have been presented by [16] (red lines) and the lineaments recognized using HGM technique (blue lines) of the study field.

When all the interface topographies are evaluated together, it is seen that the crust is generally thickened to the east. When the soft-hard sediment, basement, Conrad and Moho interfaces are formed as a result of the calculations, it is seen that the depths of these interfaces increased to the east and decreased in some parts (Figures $7 \mathrm{~b}, 7 \mathrm{~d}, 7 \mathrm{f}$ and $7 \mathrm{~h}$ ). On the other hand, due to a density difference of $0.04 \mathrm{~g} / \mathrm{cm}^{3}$, the situation is different at the depths of the LAB interface. While the depths of this interface are decreased between Sivas and Nevşehir and is about $81.4 \mathrm{~km}$, and it has $88.5 \mathrm{~km}$ depth value in the vicinity of Amasya (Figure 7j). If the gravity values of the units offering density differences are examined, it can be said that there is a relationship between the depth values of the interface topographies and the gravity values of the units in the study area. This is probably due to the low gravity values, the thickness of the crust and the density of the crust is low compared to the density of the astenosphere. In addition, the lithospheric mantle material with a high density and below the Moho boundary is deeper due to the thicker crust. Therefore, the gravity values are low. Since this is the case in all figures, the 
greatest effect is the depth of the lithospheric mantle from sea level. On the other hand, in some parts of the study area, the gravity values are low, the thickness of the crust is low and the crust density is low compared to the lithospheric mantle density. In addition, the lithospheric mantle material with a high density is close to the surface due to the thin crust. Therefore, the gravity values are high here. Since this is the case, the greatest effect that causes this is the depth of the lithospheric mantle from sea level. In other words, the lithospheric mantle, which has a high density, is upward and causes high gravity.
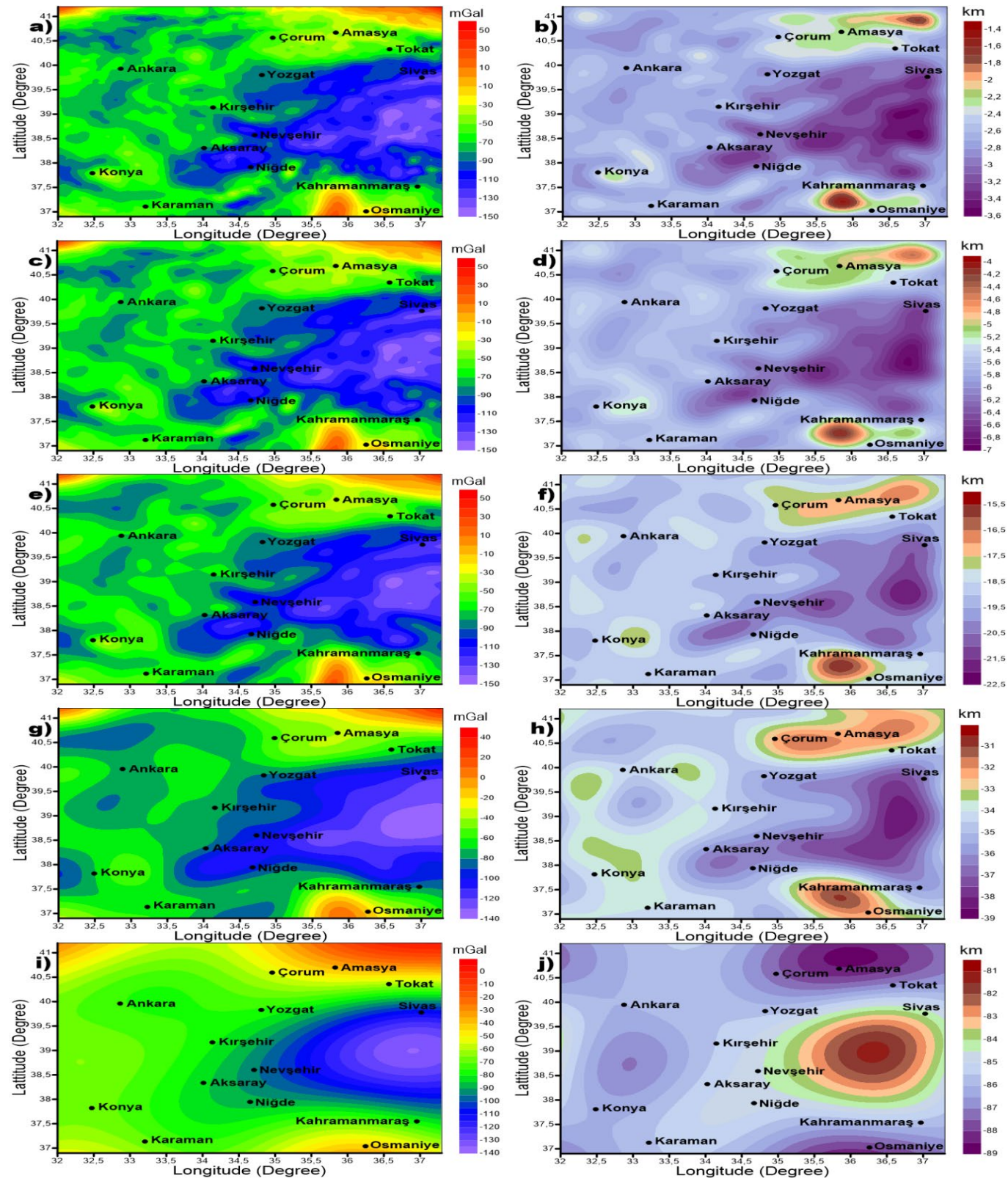

Figure 7. a) Gravity anomaly map of soft-hard sediment interface, b) Calculated topography map of soft-hard sediment interface, c) Gravity map of basement interface, d) Calculated topography map of basement interface, e) Gravity anomaly map of Conrad interface, f) Calculated topography map of Conrad interface, g) Gravity anomaly map of Moho interface, h) Calculated topography map of Moho interface, i) Gravity anomaly map of LAB interface, j) Calculated topography map of LAB interface. 


\section{Conclusions}

In this work, firstly, tectonic structure of the Central Anatolia was given by forming a linearity map. A synthetic data of five prism model structures with different sizes and depths were used to test the validity of the boundary analysis technique used to reveal the lineaments in the basement level in the study area. Then the filtered gravity data of the basement rock of the study area were obtained. The aim of investigating the lineaments at basement rock levels is that the earthquakes in the study area are grouped at the first $10 \mathrm{~km}$ depth [23]. The new lineaments determined by the HGM study are generally parallel to the known faults. In some places, new lineaments extending in various directions and new lineaments cutting the old faults are found. In addition to new lineaments, NAFZ, CATB, SAF, KEF and other important faults can be seen in the lineaments map. Using the radial mean amplitude spectrum, the mean depths calculated for the soft-hard sediment, Basement, Conrad, Moho and LAB interface topography are $2.7,5.7,19.0,34.6$ and $85.6 \mathrm{~km}$, respectively. The filtered gravity data calculated according to the determined cut-off wave numbers are analyzed by using the inverse solution and then the depths calculated for soft-hard sediment, basement, Conrad, Moho and LAB interface topographies are found to be changed between $1.4-3.6 \mathrm{~km}, 3.8-7.2 \mathrm{~km}, 15.5-22.5 \mathrm{~km}, 30.5-39.5 \mathrm{~km}$ and 81.4 $88.5 \mathrm{~km}$ respectively. While the first four interface depths from top to bottom are increasing in the east, they decrease in other places. The depth of the LAB interface was opposite the others. This interface takes the shallowest values between Sivas and Nevşehir provinces. Thus, the undulations on the crust interfaces of the study area are determined.

The soft-hard sediment interface depth values found by using inverse solution technique for Central Anatolia are compatible with the depth values found in the same region with 2D gravity inversion calculations [30]. Basement depths found with inverse solution are compatible with the depths found in the same region by using a 3D modeling study [5] and using aeromagnetic, gravity, seismic and seismological data [6]. The Conrad depths found in this study are consistent with the depth values found in the same region by using the curie point depth investigation using regional aeromagnetic anomalies [3]. The depths of the Moho interface found in this study are also consistent with the depth values found in the same region using receiver function analysis of seismic values [32]. At the end of the inverse solution studies, the depths of the LAB are given in addition to the other interfaces. In addition, the Central Anatolian crust interface topographies are given as 2 dimensional underground cross section under the five defined profiles. As a result, although there is a good agreement between the results found in this study and previous studies in the region, new results have been reached to contribute to the geology of the region.

\section{References}

[1] Altınoğlu, F.F., Sarı, M., Aydın, A., Detection of Lineaments in Denizli Basin of Western Anatolia Region Using Bouguer Gravity Data, Pure and Applied Geophysics, 172, 415-425, 2015.

[2] Arısoy, M. Ö., Dikmen, Ü., Potensoft: MATLAB-based Software for potential field data processing, modelling and mapping, Computers and Geosciences, 37, 935-942, 2011.

[3] Ateş, A., Bilim, F., Büyüksaraç, A., Curie Point Depth Investigation of Central Anatolia, Turkey, Pure and Applied Geophysics, 162, 357-371, 2005.

[4] Aydemir, A., Ateş, A., Preliminary evaluation of Central Anatolian basins in Turkey by using the gravity \& magnetic data, Journal of Balkan Geophysical Society, 8, 7-19, 2005.

[5] Aydemir, A., Ateş, A., Structural interpretation of the Tuzgölü and Haymana Basins, Central Anatolia, Turkey, using seismic, gravity and aeromagnetic data, Earth Planets Space, 58, 951-961, 2006.

[6] Aydemir, A., Tectonic investigation of Central Anatolia, Turkey, using geophysical data, Journal of Applied Geophysics, 68, 321-334, 2009. 
[7] Bhattacharyya, B.K., Some general properties of potential fields in space and frequency domain: a review, Geoexploration 5 (3), 127-143, 1967.

[8] Büyüksaraç, A., Jordanova, D., Ates, A., Karloukovski, V., Interpretation of the gravity and magnetic anomalies of the Cappadocia Region, Central Turkey, Pure and Applied Geophysics 162, $2197-$ 2213, 2005.

[9] Büyüksaraç, A., Investigation into the regional wrench tectonics of inner East Anatolia (Turkey) using potential field data, Physics of the Earth and Planetary Interiors 160, 86-95, 2007.

[10] Cooper, G.R.J., Cowan, D.R., Enhancing potential field data using filters based on the local phase, Computers and Geosciences, 32 (10), 1585-1591, 2006.

[11] Cordell, L., Grauch, V.J.S., Mapping basement magnetization zones from aeromagnetic data in the San Juan Basin, New Mexico, (Ed. Hinze, W.J.) The utility of regional gravity and magnetic anomaly maps, Society of Exploration Geophysicists, 181-197, 1985.

[12] Coşkun, B., Aksaray and Ecemis Faults-Diapiric Salt Relationships: relevance to the hydrocarbon exploration in the Tuz Gölü (Salt Lake) Basin, Central Anatolia, Turkey, Energy Sources, 26, 1005-1022, 2004.

[13] Cemen, I., Göncüoglu, C., Dirik, K., Structural evolution of the Tuzgölü Basin Central Anatolia, Turkey, The Journal of Geology, 107, 693-706, 1999.

[14] Derman, A.S., Rojay, B., Guney, H., Yildiz, M., Sereflikochisar-Aksaray Fay zonunun evrimi hakkinda yeni sedimantolojik veriler. Haymana-Tuzgölü-Ulukisla Basenleri Workshop: TAPG, Special Publication, 5, 47-70, 2000.

[15] Elmas, A., Kıbrıs Adasındaki Yapısal Süreksizliklerin EGM08 Gravite Verileri Kullanılarak Belirlenmesi, Jeoloji Mühendisliği Dergisi, 42, 17-32, 2018.

[16] Emre, Ö., Duman, T.Y., Özalp, S., Elmac1, H., Olgun, Ş., Şaroğlu, F., Açıklamalı 1/1.250.000 Ölçekli Türkiye Diri Fay Haritası, Maden Tetkik ve Arama Genel Müdürlüğü, Özel Yayın Serisi30. Ankara- Türkiye, 2013.

[17] Evjen, H. M., The place of the vertical gradient in gravitational interpretations, Geophysics, 1, 127136, 1936.

[18] Gao, X., Sun, S., Comment on «3DINVER.M: A MATLAB program to invert the gravity anomaly over a 3D horizontal density interface by Parker-Oldenburg's algorithm». Computers and Geosciences, 127, 133-137, 2019.

[19] Gomez-Ortiz, D., Agarwal, B.N.P., 3DINVER.M: A MATLAB program to invert the gravity anomaly over a 3-D horizontal density interface by Parker-Oldenburg's algorithm, Computers and Geosciences, 31, 513-520, 2005.

[20] Görür, N., Tuysuz, O., Şengör, A.M.C., Tectonic evolution of the Central Anatolian Basins, International Geology Review, 40, 831-850. 1998.

[21] Gunn, P.J., Linear transformations of gravity and magnetic fields, Geophysical Prospecting, 23 (2), 300-312, 1975.

[22] Oldenburg, D.W., The inversion and interpretation of gravity anomalies, Geophysics, 39, 526-536, 1974.

[23] Oruç, B., Sönmez, T., The rheological structure of the lithosphere in the Eastern Marmara region, Turkey, Journal of Asian Earth Sciences, 139, 183-191, 2017.

[24] Oruç, B., Gomez-Ortiz, D., Petit, C., Lithospheric flexural strength and effective elastic thicknesses of the Eastern Anatolian and surrounding region, Journal of Asian Earth Sciences, 150, 1-13, 2017.

[25] Oruç, B., Edge detection and depth estimation using a tilt angle map from gravity gradient data of the Kozakl1-Central Anatolia Region, Turkey, Pure and Applied Geophysics, 168, 1769-1780, 2011.

[26] Parker, R.L., The rapid calculation of potential anomalies, Geophysical Journal International, 31, 447-455, 1973. 
[27] Pavlis, N.K., Holmes, S.A., Kenyon, S.C., Factor. J.K., An Earth Gravitational Model to Degree 2160: EGM2008. EGU General Assembly 2008, Vienna, Austria, April 13-18, 2008. http://earthinfo.nga.mil/GandG/wgs84/gravitymod/egm2008. (Ziyaret tarihi: 11 Şubat 2019), 2008.

[28] Şengor, A.M.C., Görür, N., Saroglu, F., Strike-slip faulting and related basin formation in zones of tectonic escape: Turkey as a case study. Special Publication, Society of Economic Paleontologists and Minerologists, 37, 227-264, 1985.

[29] Şengör, A.M.C., Y1lmaz, Y., Tethyan evolution ol Turkey: A plate tectonic approach, Tectonophysics, 75, 181 - 241, 1981.

[30] Şeren, A., Çavsak, H., Jacoby, W., Calculation and inversion of two-dimensional gravity in the vicinity of Lake Tuz, Turkey, Journal of Geodynamics, 29, 87-102, 2000.

[31] U.S. Geological Survey, Digital Elevation Models GTOPO30, Virginia, 1998. http://webmap.ornl.gov/wcsdown/wcsdown.jsp?dg_id=10003_1, (Accessed 8 Feb 2021).

[32] Vanacore, E.A., Taymaz, T., Saygin, E., Moho structure of the Anatolian Plate from receiver function analysis, Geophysical Journal International, 193, 329-337, 2013. 